\title{
Nesfatin-1 protects H9c2 cardiomyocytes against cobalt chloride-induced hypoxic injury by modulating the MAPK and Notch1 signaling pathways
}

Mingchen $L i^{i^{*}}$, Kai Li ${ }^{2}$ and Yuan Ren ${ }^{1^{*}}$

\begin{abstract}
Background: This study aimed to explore the effect of nesfatin-1 on cobalt chloride $\left(\mathrm{CoCl}_{2}\right)$-induced hypoxic injury in cardiomyocyte H9c2 cells.

Methods: $\mathrm{H} 9 \mathrm{c} 2$ cardiomyocytes were induced by different concentrations of $\mathrm{CoCl}_{2}$ to mimic the hypoxia condition. Cell viability was detected by MTT assay. Cell apoptosis was detected by TUNEL staining and flow cytometry. ROS production was detected using the fluorescence probe DCFH-DA. The mitochondrial membrane potential (MMP) was detected using the TMRE method. The levels of released lactate dehydrogenase (LDH), malondialdehyde (MDA), superoxide dismutase (SOD), glutathione (GSH), and catalase (CAT) were detected using the commercial kits. The protein levels of MAPK signaling members (p-JNK1/2, p-ERK1/2, and p-p38) and Notch1 signaling members (Notch1, Hes 1 , and Jagged 1) were detected by Western blot.

Results: $\mathrm{CoCl}_{2}$ significantly promoted cell apoptosis, increased LDH leakage, MDA concentration, and decreased cell viability, SOD activity, GSH production, and CAT activity. $\mathrm{CoCl}_{2}$-induced hypoxic injury in $\mathrm{H} 9 \mathrm{c} 2$ cells was partially restored by nesfatin- 1 treatment. Moreover, nesfatin- 1 treatment attenuated $\mathrm{CoCl}_{2}$-induced increase in $\mathrm{ROS}$ production and mitochondrial dysfunction, decreased mitochondrial membrane potential, Bax/BCl-2 imbalance, as well as c-caspase-9 and c-caspase-3 levels. Moreover, nesfatin-1 treatment inhibited the activation of MAPK and Notch1 signaling pathways.
\end{abstract}

Conclusions: Nesfatin-1 could effectively protect $\mathrm{H} 9 \mathrm{c} 2$ cells against $\mathrm{CoCl}_{2}$-induced hypoxic injury by blocking MAPK and Notch 1 signaling pathways, suggesting that nesfatin-1 might be a promising therapeutic agent for hypoxic cardiac injury.

Keywords: $\mathrm{CoCl}_{2}$, Nesfatin-1, ROS, MAPK, Notch1

\footnotetext{
*Correspondence: Mingchentree@163.com; fz0142@163.com

${ }^{1}$ Department of Cardiology, The People's Hospital of Jiulongpo, No. 31

Baixin Road, Baishiyi, Jiulongpo, 401329 Chongqing, People's Republic of China

Full list of author information is available at the end of the article
}

\section{Background}

In the past decades, numerous studies have demonstrated that hypoxia-induced dysfunction is one of the most important components of numerous diseases [1]. Tissue hypoxia is often caused by oxygen partial pressure in arterial blood and disruptive blood flow [2]. Previous studies have reported that the imbalance between $\mathrm{O}_{2}$ supply and the heart's demand may cause distant organ original author(s) and the source, provide a link to the Creative Commons licence, and indicate if changes were made. The images or other third party material in this article are included in the article's Creative Commons licence, unless indicated otherwise in a credit line to the material. If material is not included in the article's Creative Commons licence and your intended use is not permitted by statutory regulation or exceeds the permitted use, you will need to obtain permission directly from the copyright holder. To view a copy of this licence, visit http://creativecommons.org/licenses/by/4.0/. The Creative Commons Public Domain Dedication waiver (http://creativeco mmons.org/publicdomain/zero/1.0/) applies to the data made available in this article, unless otherwise stated in a credit line to the data. 
damages [3]. Hypoxia occurred in hearts may lead to cardiomyocyte injury, which is involved in various serious heart diseases such as myocardial infarction and ischemic stroke $[4,5]$. Therefore, inhibition of hypoxiainduced cardiomyocyte damages is a promising therapeutic strategy for hypoxic cardiac injury.

In a hypoxic state, mitochondria may be a threat to cells due to the production of reactive oxygen species (ROS) [6]. The excess ROS may result in cardiomyocyte damages, including apoptosis which is characterized by the increased release of lactate dehydrogenase (LDH) and malondialdehyde (MDA) and decreased superoxide dismutase (SOD), glutathione (GSH), and catalase (CAT) [7]. The mitogen-activated protein kinase (MAPK) family is highly conserved and known to respond to various stresses via transmitting the signals from cytoplasmic to nuclear targets, which is mediated by a phosphorylation cascade [8]. MAPK signaling pathway has been identified to be associated with cardiomyocyte apoptosis triggered by ROS [9]. Another signaling pathway triggered by ROS is the Notch pathway, and activation of the Notch pathway can induce downstream proteins involved in the cell cycle and apoptosis, including Notch1, Hes-1, Hes-5, and Jagged1 $[10,11]$. These reports indicate that targeting MAPK and Notch1 signaling pathways may be a potential treatment to prevent ROS-induced cardiomyocyte injury.

Nesfatin-1 is an 82 amino acid polypeptide derived from the nucleobindin 2 (NUCB2) protein [12]. Increasing evidence has revealed its wide functions in human diseases. For example, nesfatin-1 is identified earliest to participate in the regulation of food intake by acting as an anorexigenic peptide to cause weight loss and malnutrition [13]. Nesfatin-1 exerts cardiovascular protective effects by inhibiting peripheral arterial remodeling [14]. In addition, nesfatin-1 also plays important roles in different types of cancers, such as gastric cancer [15], bladder cancer [16], colon cancer [17], ovarian epithelial carcinoma [18], and so on. Recently, Nazarnezhad et al. demonstrated that nesfatin-1 could significantly reduce high glucose-induced intracellular ROS production in PC12 cells in diabetic neuropathy [19], suggesting that nesfatin-1 might have potential roles in hypoxia-induced cell injury.

Cobalt chloride $\left(\mathrm{CoCl}_{2}\right)$ is widely used to mimic hypoxia conditions [20]. This study found that $\mathrm{CoCl}_{2}$ significantly promoted cell apoptosis and decreased cell viability while increased ROS production and caused mitochondrial abnormalities. Meanwhile, the expression of MAPK signaling members (p-JNK1/2, p-ERK1/2, and $\mathrm{p}-\mathrm{p} 38$ ) and Notch1 signaling members (Notch1, Hes 1 , and Jagged 1) was evaluated by $\mathrm{CoCl}_{2}$ treatment. Moreover, our study revealed that nesfatin-1 effectively attenuated $\mathrm{CoCl}_{2}$-induced $\mathrm{H} 9 \mathrm{c} 2$ cell injury by inhibiting MAPK and Notch1 signaling pathways, suggesting that nesfatin-1 might be an effective agent against cardiac hypoxia.

\section{Methods \\ Cell culture}

Rat embryonic cardiomyocyte cell line $\mathrm{H} 9 \mathrm{c} 2$ was obtained from ATCC (Rockville, USA) and cultured in DMEM containing 10\% FBS (Gibco, Carlsbad, CA, USA) at $37^{\circ} \mathrm{C}$ and additional $5 \% \mathrm{CO}_{2}$.

\section{MTT assay}

Cell viability was measured using the MTT assay kit (ab211091, Abcam, USA). In brief, approximately $5 \times 10^{4}$ cells were placed into each well of 96-well plates and cultured overnight. To evaluate the effect of $\mathrm{CoCl}_{2}$, cells were treated with $\mathrm{CoCl}_{2}$ at different concentrations (400, $500,600,800,1000$, and $1200 \mu \mathrm{M}$ ) for 24 or $48 \mathrm{~h}$. To evaluate the effect of nesfatin-1, cells were treated with nesfatin-1 at different concentrations $(10,20,40,60,80,100$, and $120 \mathrm{nM}$ ) after incubation with $800 \mu \mathrm{M} \mathrm{CoCl}_{2}$ for $48 \mathrm{~h}$ for another $24 \mathrm{~h}$. Subsequently, $5 \mathrm{mg} \mathrm{ml}^{-1} \mathrm{MTT}$ reagent was added to each well, and the plates were incubated for $4 \mathrm{~h}$. The absorption at $570 \mathrm{~nm}$ was detected with an ELISA plate reader.

\section{TUNEL staining assay}

The apoptotic cells were visualized using TUNEL Apoptosis Detection Kit (Yeasen, Shanghai, China). Approximately, $1 \times 10^{5}$ cells per well were seeded into 24-well plates and treated with $800 \mu \mathrm{M} \mathrm{CoCl}{ }_{2}$ for 48 h before treated with nesfatin-1 at different concentrations (20, 60 , and $80 \mathrm{nM}$ ) for another $24 \mathrm{~h}$. Then cells were incubated with Alexa Fluor 488-12-dUTP Labeling Mix for $20 \mathrm{~min}$, and the nuclei were counterstained by DAPI solution. The apoptotic cells were counted under a fluorescence microscope (Olympus, Tokyo, Japan) $(\times 40)$.

\section{Annexin $\mathrm{V}$ apoptosis assay}

Cell apoptosis was detected using the Annexin V-APC and 7-AAD Apoptosis Detection reagent (BD Biosciences) as previously described [21]. Briefly, $2 \times 10^{5}$ cells per well were plated into 6-well plates and treated with $800 \mu \mathrm{M} \mathrm{CoCl}_{2}$ for $48 \mathrm{~h}$ before treatment with nesfatin-1 at different concentrations $(20,60$, and $80 \mathrm{nM})$ for another $24 \mathrm{~h}$. Afterward, cells were washed and incubated Annexin V-conjugated APC and 7-AAD. Cell apoptosis was detected using a flow cytometer (Beckman, Pasadena, USA). 


\section{Western blot}

Total proteins were extracted from the cultured cells using RIPA lysis buffer containing 1\% NP-40, $0.1 \%$ SDS, $0.5 \%$ sodium deoxycholate, $50 \mathrm{mM}$ Tris $\mathrm{pH} 7.5$, and $150 \mathrm{mM} \mathrm{NaCl}$ (Beyotime Institute of Biotechnology, Shanghai, China). Approximately equal amounts of protein samples $(25 \mu \mathrm{g})$ were separated by $12 \%$ SDSPAGE and transferred onto PVDF membranes. After blocking in 5\% nonfat milk, the membranes were incubated overnight at $4{ }^{\circ} \mathrm{C}$ with primary antibodies against p38 (ab31828, 1:1000, Abcam, USA), p-p38 (ab195049, 1:1000, Abcam, USA), ERK1/2 (ab184699, 1:1000, Abcam, USA), p-ERK1/2 (ab223500, 1:1000, Abcam, USA), JNK1/2 (\#9255, 1:1000, Cell Signaling Technology, USA), p-JNK1/2 (\#4668, 1:1000, Cell Signaling Technology, USA), Notch1 (\#3608, 1:1000, Cell Signaling Technology, USA), Hes 1 (\#11,988, 1:1000, Cell Signaling Technology, USA), Jagged 1 (\#70109, 1:1000, Cell Signaling Technology, USA), Bax (ab32503, 1:1000, Abcam, USA), Bcl2 (ab32124, 1:1000, Abcam, USA), c-caspase-9 (ab2324, 1:1000, Abcam, USA), c-caspase-3 (ab32042, 1:1000, Abcam, USA) and $\beta$-actin (ab8226, 1:10,000, Abcam, USA). On the next day, the membranes were then incubated with HRP-conjugated secondary antibody for $2 \mathrm{~h}$. The antibody-bound proteins were detected using an ECL chemiluminescence detection kit (Thermo Fisher Scientific, Waltham, MA, USA).

\section{Measurement of intracellular ROS}

The intracellular ROS in $\mathrm{H} 9 \mathrm{c} 2$ cells after different treatments was detected using $2^{\prime}, 7^{\prime}$-dichlorodihydrofluorescein diacetate (DCFH-DA) probe (Sigma Chemicals Co., USA) as previously reported [22]. Briefly, $5 \times 10^{5}$ cells per well were seeded into 24-well plates and treated with $800 \mu \mathrm{M} \mathrm{CoCl}_{2}$ for $48 \mathrm{~h}$, followed by 20,60 , and $80 \mathrm{nM}$ nesfatin-1 for $24 \mathrm{~h}$. After addition of $25 \mu \mathrm{M}$ DCF-DA solution, the plates were incubated for $30 \mathrm{~min}$, and the fluorescence of DCF was detected using a microplate reader (Bio-Rad, USA).

\section{Detection of LDH, MDA, SOD, GSH, and CAT}

Approximately $2 \times 10^{5}$ cells per well were plated into 24-well plates and treated with $800 \mu \mathrm{M} \mathrm{CoCl}_{2}$ for $48 \mathrm{~h}$, followed by 20, 60, and $80 \mathrm{nM}$ nesfatin- 1 for $24 \mathrm{~h}$. The levels of released LDH, MDA, SOD, GSH, and CAT in the supernatant were detected using specific detection kits.

\section{Detection of mitochondrial membrane potential (MMP)}

The MMP was detected as previously described [23]. In brief, $5 \times 10^{5}$ cells per well were plated into 6-well plates and treated with $800 \mu \mathrm{M} \mathrm{CoCl}_{2}$ for $48 \mathrm{~h}$, followed by 20 ,
60 , and $80 \mathrm{nM}$ nesfatin-1 for $24 \mathrm{~h}$. The cells were incubated with $2.5 \mathrm{nM}$ tetramethylrhodamine ethyl ester (Sigma-Aldrich, St Louis, MO, USA; Merck KGaA, Darmstadt, Germany) for $25 \mathrm{~min}$. After cells were washed with PBS twice, the fluorescence at $490 \mathrm{~nm}$ (excitation)/590nm (emission) was detected using a flow cytometer (Beckman, Pasadena, USA).

\section{Statistical analysis}

The data were presented as mean \pm SD (standard deviation). Data analysis was performed in SPSS ver. 22.0 (IBM Corp, Armonk, NY, USA). The difference between two groups was tested using Student's $t$ test $p<0.05$ was considered significant.

\section{Results}

$\mathrm{CoCl}_{2}$ inhibited proliferation, induced apoptosis, and activated MAPK and Notch1 signaling pathways in $\mathrm{H} 9 \mathrm{c} 2$ cells

To confirm the toxicity of $\mathrm{CoCl}_{2}$ in $\mathrm{H} 9 \mathrm{c} 2$ cells, $\mathrm{H} 9 \mathrm{c} 2$ cells were treated with different concentrations of $\mathrm{CoCl}_{2}$ for 24 or $48 \mathrm{~h}$. MTT assay showed that treatment with $\mathrm{CoCl}_{2}$ at $600,800,1000$, and $1200 \mu \mathrm{M}$ significantly reduced the viability of $\mathrm{H} 9 \mathrm{c} 2$ cells at both $24 \mathrm{~h}(p<0.05$, Fig. 1A) and $48 \mathrm{~h}(p<0.05$, Fig. 1B). TUNEL staining (Fig. 1C) and flow cytometry analyses (Fig. 1D) indicated that treatment with $800 \mu \mathrm{M} \mathrm{CoCl}_{2}$ for $48 \mathrm{~h}$ significantly promoted apoptosis of H9c2 cells $(p<0.05)$. In addition, $\mathrm{CoCl}_{2}$ treatment increased the levels of MAPK signaling members (p-JNK1/2, p-ERK1/2, and p-p38) and Notch1 signaling members (Notch1, Hes 1, and Jagged 1; $p<0.05$; Fig. 1E, F). These results suggested that $\mathrm{CoCl}_{2}$ could significantly inhibit proliferation, induce apoptosis, and activate MAPK and Notch1 signaling pathways in H9c2 cells.

\section{Nesfatin-1 protected $\mathrm{H} 9 \mathrm{c} 2$ cells against $\mathrm{CoCl}_{2}$-induced cytotoxicity}

To explore whether nesfatin- 1 is cytotoxic, H9c2 cells were treated with nesfatin-1 at 10, 20, 40, 60, 80, 100, and $120 \mathrm{nM}$ for $24 \mathrm{~h}$, and the cytotoxicity of nesfatin-1 against H9c2 cells were examined. MTT assay indicated that cell viability was not significantly changed after 10 to $80 \mathrm{nM}$ nesfatin-1 treatment but significantly decreased after $100-120 \mathrm{nM}$ nesfatin-1 treatment ( $p<0.05$; Fig. 2A). To explore the effect of nesfatin- 1 on $\mathrm{CoCl}_{2}$-induced cytotoxicity, $\mathrm{H} 9 \mathrm{c} 2$ cells were treated with $800 \mu \mathrm{M} \mathrm{CoCl}_{2}$ for $48 \mathrm{~h}$ before incubation with 20,60, and $80 \mathrm{nM}$ nesfatin-1 for $24 \mathrm{~h}$. MTT assay indicated that nesfatin-1 significantly reduced $\mathrm{CoCl}_{2}$-induced cytotoxicity and enhanced cell viability ( $p<0.05$; Fig. $2 \mathrm{~B})$. In addition, TUNEL staining assay (Fig. 2C, E) and flow cytometry analysis (Fig. 2D, F) also showed that $\mathrm{CoCl}_{2}$-induced apoptosis in 


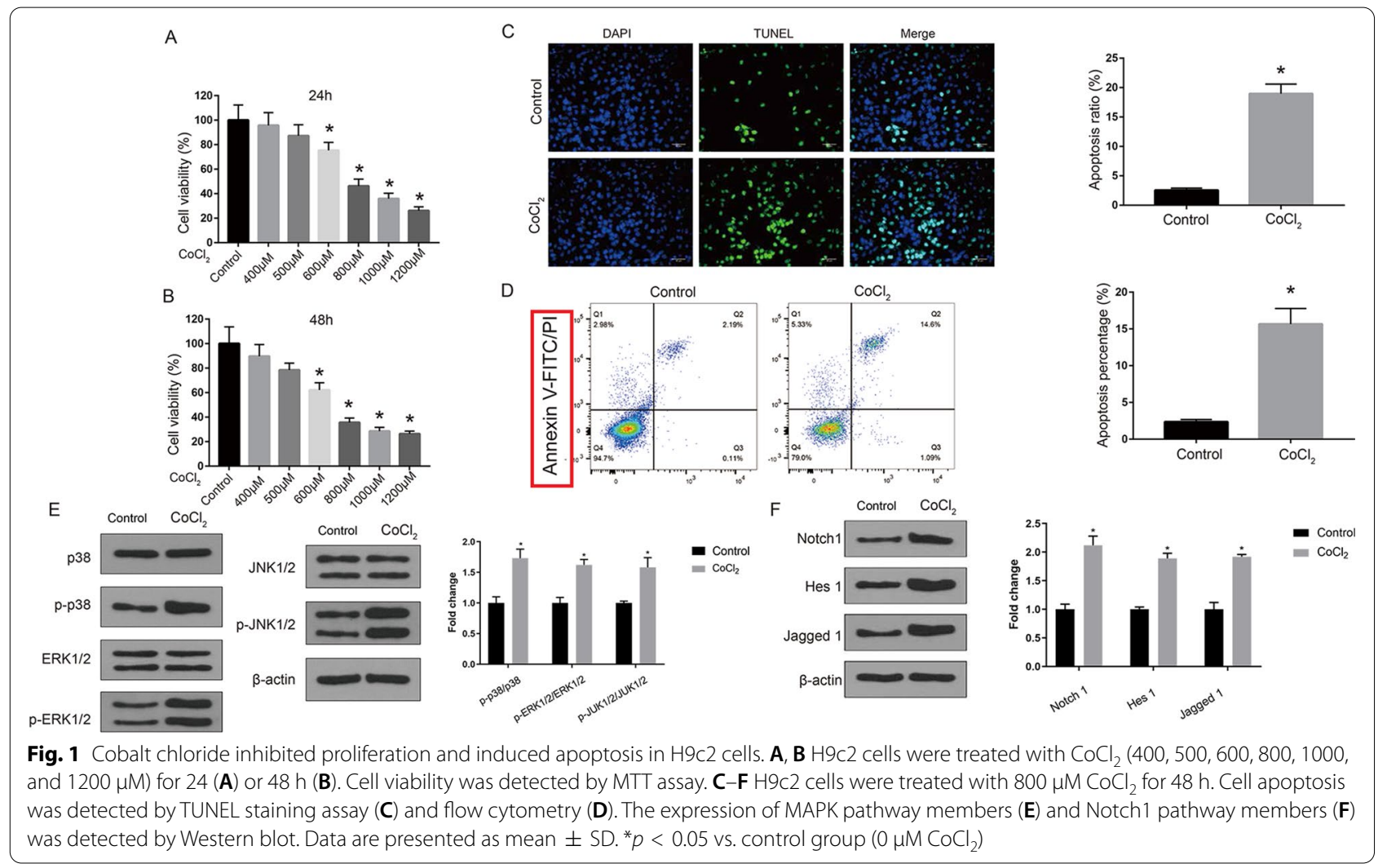

H9c2 cells was partially attenuated by nesfatin-1 treatment $(p<0.05)$, suggesting a potential cytoprotective effect of nesfatin-1 against $\mathrm{CoCl}_{2}$-induced apoptosis. Moreover, $\mathrm{CoCl}_{2}$ treatment significantly increased the release of LDH in H9c2 cells $(p<0.05)$, and nesfatin-1 effectively reverse this phenomenon $(p<0.05$; Fig. $2 \mathrm{G})$. These results suggested that nesfatin-1 protected $\mathrm{H} 9 \mathrm{c} 2$ cells against $\mathrm{CoCl}_{2}$-induced apoptosis.

\section{Nesfatin-1 protected $\mathrm{H} 9 \mathrm{c} 2$ cells against $\mathrm{CoCl}_{2}$-induced ROS production}

Then we explored the effect of nesfatin-1 on $\mathrm{CoCl}_{2}$-induced ROS production. The intracellular ROS levels increased after $\mathrm{CoCl}_{2}$ treatment $(p<0.05)$, and nesfatin-1 significantly decreased intracellular ROS levels induced by $\mathrm{CoCl}_{2}(p<0.05)$, further confirming the antioxidant effect of nesfatin-1 (Fig. 3A). In addition, $\mathrm{CoCl}_{2}$ treatment significantly increased MDA concentration $(p<0.05)$, while reduced SOD activity $(p<0.05)$, GSH production $(p<0.05)$, and CAT activity $(p<0.05)$, and the oxidative abnormalities were obviously ameliorated by nesfatin-1 treatment $(p<0.05$, Fig. 3B-E). These results revealed that nesfatin-1 effectively protected $\mathrm{H} 9 \mathrm{c} 2$ cells against $\mathrm{CoCl}_{2}$-induced ROS production and oxidative abnormalities.

\section{Nesfatin-1 protected $\mathrm{H} 9 \mathrm{c} 2$ cells against $\mathrm{CoCl}_{2}$-induced mitochondrial abnormalities}

Next, we explored the effect of nesfatin-1 on $\mathrm{CoCl}_{2}$-induced mitochondrial membrane potential (MMP) abnormalities. The results showed that $\mathrm{CoCl}_{2}$ treatment significantly decreased MMP of H9c2 cells $(p<0.05)$, while 60 and $80 \mathrm{nM}$ rather than $20 \mathrm{nM}$ nesfatin-1 obviously attenuated the loss of MMP induced by $\mathrm{CoCl}_{2}(p<0.05$; Fig. 4A). Meanwhile, Western blot (Fig. 4B) indicated that $\mathrm{CoCl}_{2}$ treatment significantly increased Bax, c-caspase-9, and c-caspase- 3 levels while downregulated $\mathrm{Bcl}-2$ level in H9c2 cells $(p<$ 0.05 ), and the abnormal expression of these apoptosisrelated proteins was attenuated by 60 and $80 \mathrm{nM}$ nesfatin-1 treatment ( $p<0.05$, Fig. $4 \mathrm{C}-\mathrm{F})$. These results demonstrated that nesfatin-1 could effectively protect $\mathrm{H} 9 \mathrm{c} 2$ cells against $\mathrm{CoCl}_{2}$-induced mitochondrial abnormalities and apoptosis. 
A

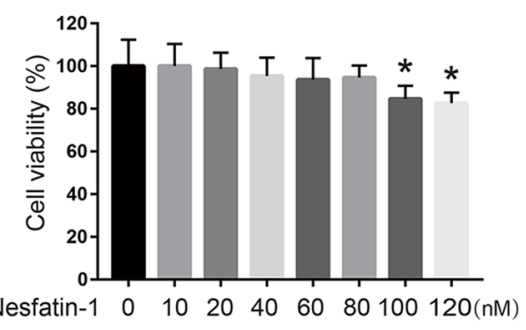

C

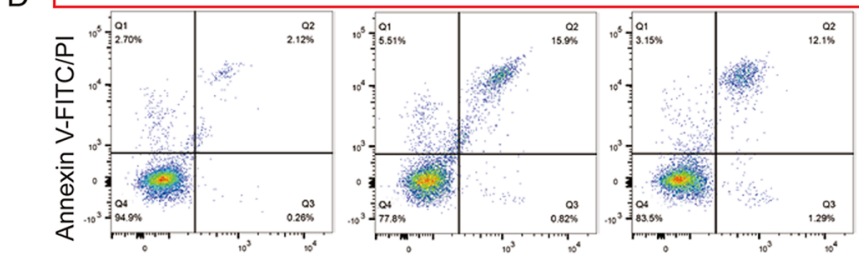

E

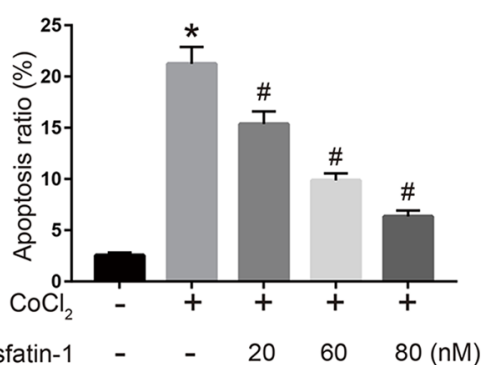

$\mathrm{F}$

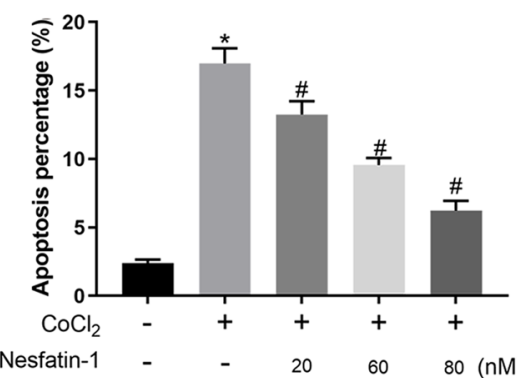

B

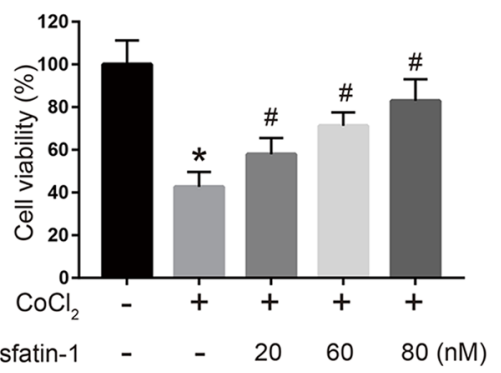

Fig. 2 Nesfatin-1 protected $\mathrm{H} 9 \mathrm{c} 2$ cells against $\mathrm{CoCl}_{2}$-induced cytotoxicity. $\mathbf{A} \mathrm{H} 9 \mathrm{c} 2$ cells were treated with nesfatin-1 (10, 20, 40, 60, 80, 100 and 120 $\mathrm{nM}$ ) for $24 \mathrm{~h}$, and cell viability was detected by MTT assay. B-G H9c2 cells were treated with $800 \mu \mathrm{M} \mathrm{CoCl}_{2}$ for $48 \mathrm{~h} \mathrm{before} \mathrm{treatment} \mathrm{with} \mathrm{different}$ concentrations of nesfatin-1 (20,60 and 80 nM) for 24 h. B Cell viability was detected by MTT assay. Cell apoptosis was evaluated using TUNEL staining assay $(\mathbf{C}, \mathbf{E})$ and flow cytometry $(\mathbf{D}, \mathbf{F})$. G The release of LDH in the supernatant was detected using corresponding detection kit. Data are presented as mean $\pm \mathrm{SD}$. ${ }^{*} p<0.05$ vs. control group $(0 \mu \mathrm{M} \mathrm{CoCl})$; $\# p<0.05$ vs. $\mathrm{CoCl}_{2}$ alone group $(800 \mu \mathrm{M} \mathrm{CoCl} 2$ and 0 nM nesfatin-1)

\section{Nesfatin-1 protected $\mathrm{H} 9 \mathrm{c} 2$ cells against $\mathrm{CoCl}_{2}$-induced hypoxic injury by inhibiting MAPK and Notch1 signaling pathways}

Finally, we explored the effects of nesfatin-1 on $\mathrm{CoCl}_{2}$-induced MAPK and Notch1 signaling pathways. Western blot indicated that $\mathrm{CoCl}_{2}$ treatment significantly increased the levels of MAPK pathway members (p-JNK1/2, p-ERK1/2, and p-p38) and Notch1 pathway members (Notch1, Hes 1 , and Jagged 1$)(p<0.05)$, while these elevations were attenuated by 60 and $80 \mathrm{nM}$ nesfatin- 1 treatment ( $p<0.05$; Fig. 5A, B). In addition, 20 nM Nesfatin-1 treatment alleviated $\mathrm{CoCl}_{2}$-induced upregulation of Hes 1 protein ( $p<0.05$; Fig. 5B). Overall, the results indicated that nesfatin-1 treatment protected $\mathrm{H} 9 \mathrm{c} 2$ cells against $\mathrm{CoCl}_{2}$-induced hypoxic injury by inhibiting MAPK and Notch1 signaling pathways.

\section{Discussion}

Hypoxia is a leading cause of irreversible organ damages, including the heart [24]. H9c2 cell line is widely used to explore the mechanism of hypoxia-induced cell damages [25]. $\mathrm{CoCl}_{2}$ is a well-known hypoxia-mimetic chemical reagent in vitro and in vivo $[26,27]$. Consistently, treatment with $\mathrm{CoCl}_{2}$ at different concentrations decreased 

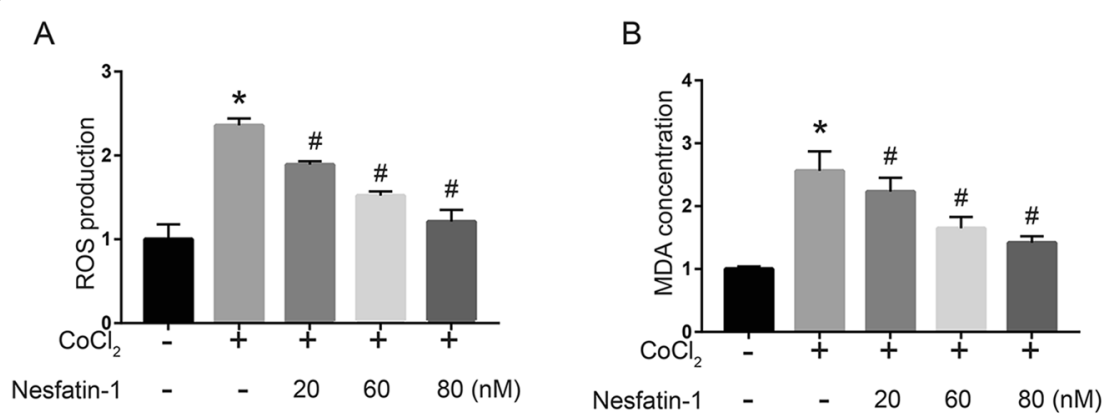

\section{C}
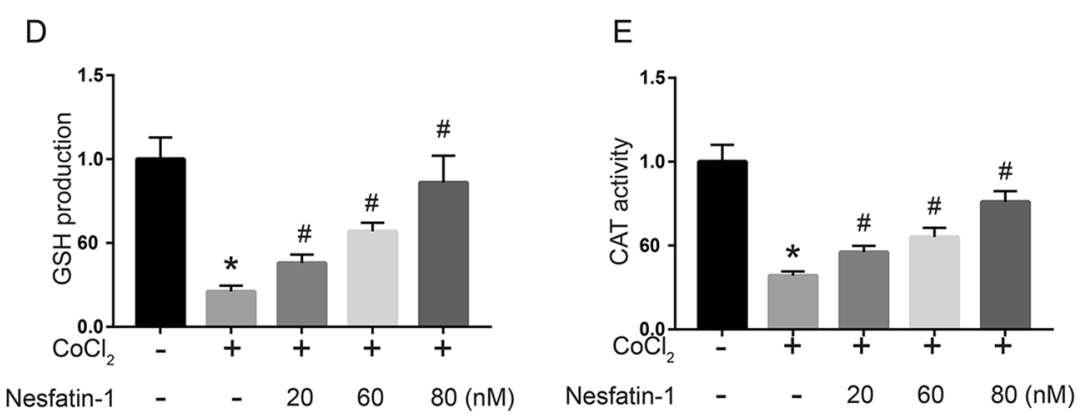

Fig. 3 Nesfatin-1 protected $\mathrm{H} 9 \mathrm{c} 2$ cells against $\mathrm{CoCl}_{2}$-induced ROS production. $\mathrm{H} 9 \mathrm{c} 2$ cells were treated with $800 \mu \mathrm{M} \mathrm{CoCl}$ for $48 \mathrm{~h}$, before treatment with nesfatin-1 (20, 60 and $80 \mathrm{nM}$ ) for $24 \mathrm{~h}$. A The ROS level was detected using a fluorescence probe (DCFH-DA). The levels of released MDA (B), SOD (C), GSH (D) and CAT (E) in the supernatant were detected by corresponding detection kits. Data are presented as mean \pm SD. ${ }^{*} p<0.05$ vs. control group $\left(0 \mu \mathrm{M} \mathrm{CoCl}_{2}\right)$; $\# p<0.05$ vs. $\mathrm{CoCl}_{2}$ alone group $\left(800 \mu \mathrm{M} \mathrm{CoCl}_{2}\right.$ and $0 \mathrm{nM}$ nesfatin- 1$)$

H9c2 viability and increased H9c2 apoptosis [28]. Importantly, the study revealed the significant protective effects of nesfatin-1 on $\mathrm{CoCl}_{2}$-induced cell injury. Moreover, our findings demonstrated that nesfatin-1 inhibits the activation of MAPK and Notch1 signaling pathways.

Due to the severe harm of hypoxia to the cardiomyocytes in the heart development, including decreased cell viability and enhanced cell apoptosis [29], several potential protective agents against hypoxia-induced injury in cardiomyocytes have been identified. For example, ginsenoside (Gin) Rg1 protects cardiomyocytes through upregulating the PI3K/AKT/mTOR pathway [30]. Astragaloside IV (AS-IV) protects cardiomyocytes by activating long non-coding RNA GAS5 mediated PI3K/mTOR signaling pathway [31]. Genistein (Gen) prevents cardiomyocytes from hypoxia-induced cell apoptosis by inhibiting the mitochondrial apoptotic pathway [32]. Ganoderic acid A (GAA) protects cardiomyocytes through upregulating miR-182-5p, downregulating PTEN, and activating PI3K/AKT signaling pathway [33]. Haemin attenuates hypoxia-induced cardiac injuries by reducing mitochondrial fission and cell apoptosis [34]. In addition, relaxin [35], sanggenon C [36], and trimetazidine [37] are potential agents against hypoxia-induced injury in cardiomyocytes. Although these agents exert certain protective effects on hypoxia-induced injury, some of them are toxic to other organs at high doses [38]. In this study, we found that 100-120 nM nesfatin-1 reduced the viability of H9c2 cells, indicating that high dose nesfatin-1 is toxic to cardiomyocytes. Hence, we selected the low dose nesfatin-1 to explore its effect and demonstrated that $20-80 \mathrm{nM}$ nesfatin-1 could effectively attenuate $\mathrm{CoCl}_{2}$-induced injuries to $\mathrm{H} 9 \mathrm{c} 2$ cells.

Oxidative stress is a key element leading to cell apoptosis in various pathological conditions [39]. ROS overproduction alters the mitochondrial structures, induces mitochondrial depolarization, decreases MMP, enhances pro-apoptotic molecule release, and causes cell apoptosis [40]. Previous studies have revealed that superoxide generation by the electron transport chain was elevated at hypoxia condition, resulting in ROS accumulation [41]. Here, $\mathrm{CoCl}_{2}$ was used to mimic the hypoxia condition, and $\mathrm{CoCl}_{2}$ treatment significantly reduced the viability and promoted apoptosis of H9c2 cells, stimulated ROS production, and led to cell injuries. Moreover, the $\mathrm{CoCl}_{2}$-induced damages to $\mathrm{H} 9 \mathrm{c} 2$ cells were partially eliminated by the addition of nesfatin-1, suggesting that nesfatin-1 might be a potential protective agent against hypoxia-induced injuries.

Bcl-2, an anti-apoptotic factor, and Bax, a pro-apoptotic factor, are two crucial apoptosis-related proteins in the Bcl-2 family [42, 43]. In this study, we found that 
A

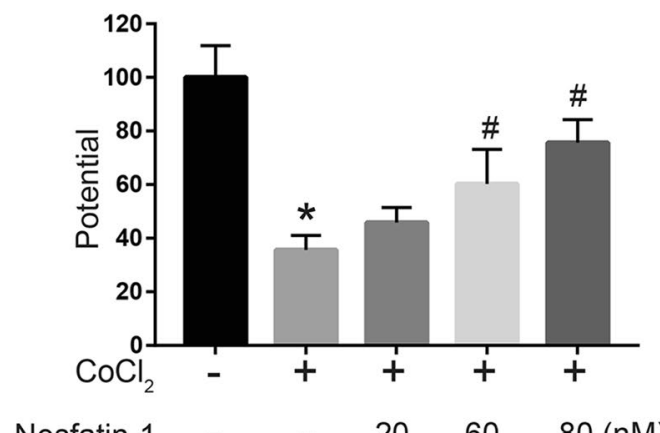

B

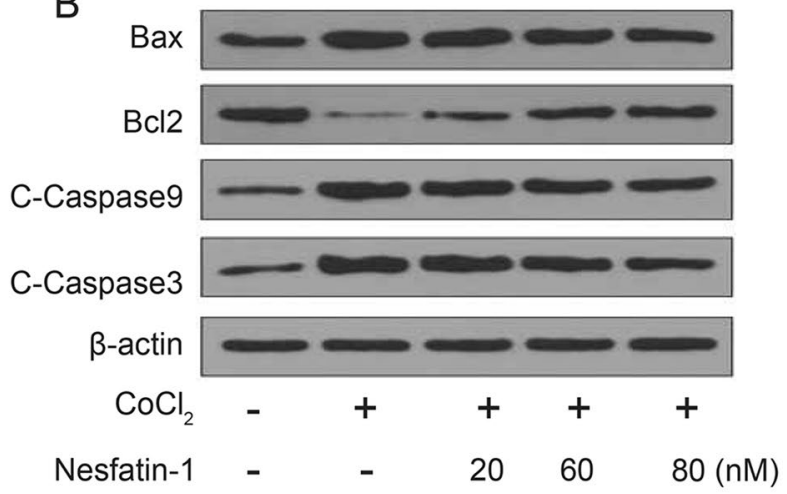

C

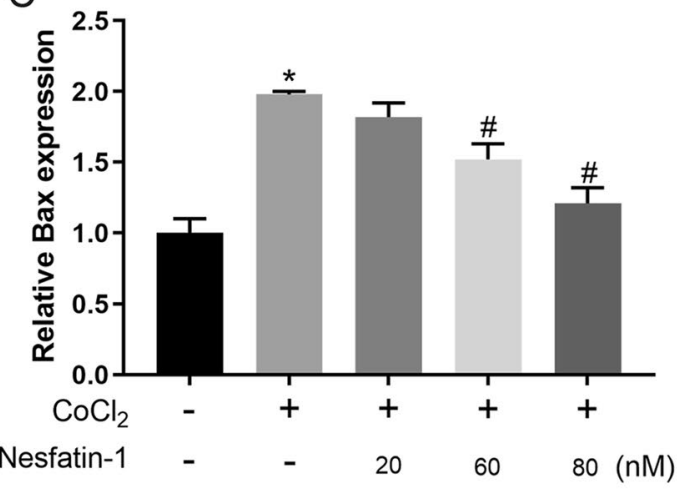

D

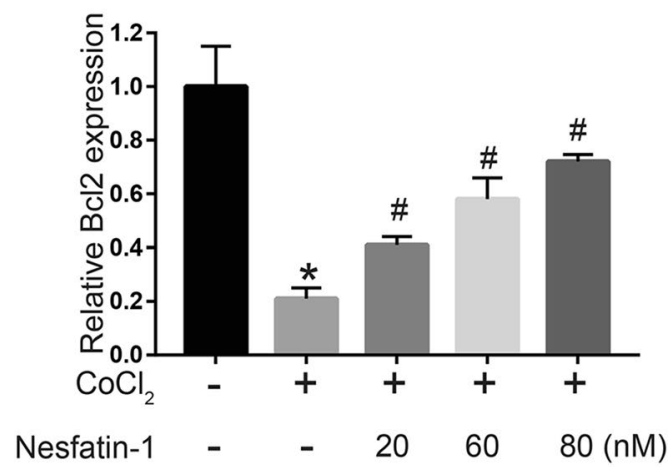

F

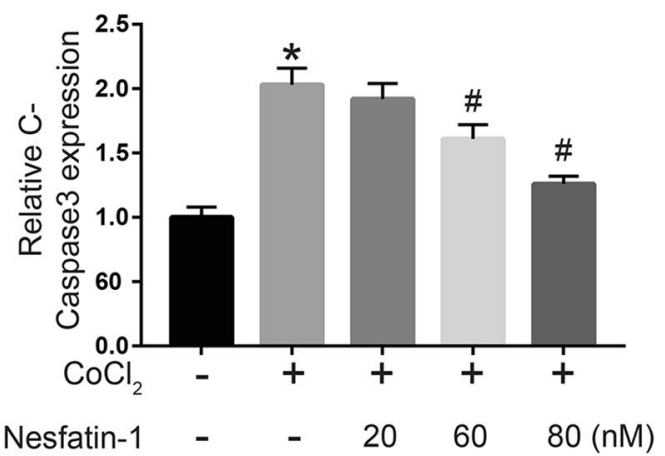

Fig. 4 Nesfatin-1 protected $\mathrm{H} 9 \mathrm{c} 2$ cells against $\mathrm{CoCl}_{2}$-induced mitochondrial abnormalities. $\mathrm{H} 9 \mathrm{c} 2$ cells were treated with $800 \mu \mathrm{M} \mathrm{CoCl}{ }_{2}$ for $48 \mathrm{~h}$, before treatment with nesfatin-1 (20,60 and $80 \mathrm{nM})$ for $24 \mathrm{~h}$. A The MMP was detected using tetramethylrhodamine ethyl ester staining assay. B-F The expression of apoptosis-related proteins was detected by Western blot. Data are presented as mean \pm SD. ${ }^{*} p<0.05$ vs. control group $(0$ $\mu \mathrm{M} \mathrm{CoCl} 2) ; \# p<0.05$ vs. $\mathrm{CoCl}_{2}$ alone group $(800 \mu \mathrm{M} \mathrm{CoCl} 2$ and 0 nM nesfatin- 1$)$

$\mathrm{CoCl}_{2}$ treatment significantly increased Bax, c-caspase-3, and c-caspase-9 levels while decreased the Bcl-2 level. Meanwhile, $\mathrm{CoCl}_{2}$ treatment-induced changes in apoptosis-related protein levels in $\mathrm{H} 9 \mathrm{c} 2$ cells were reversed by nesfatin-1 treatment. Previous studies have demonstrated that ROS-dependent activation of MAPK and Notch1 signaling pathways was required for $\mathrm{CoCl}_{2}$-induced cell death in cardiomyocytes [32, 44]. Our results confirmed that the activation of MAPK and Notch1 signaling was associated with $\mathrm{CoCl}_{2}$-induced $\mathrm{H} 9 \mathrm{c} 2$ cell apoptosis, and the activation of MAPK and Notch1 signaling pathways was markedly inhibited by nesfatin-1 treatment.

The role of Notch1 signaling in the hypoxia-injured cardiomyocytes is controversial. Boccalini et al. [45] 


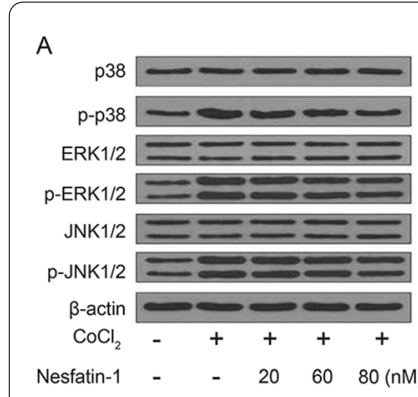

B

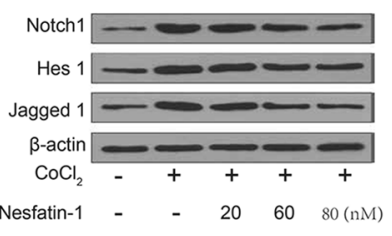

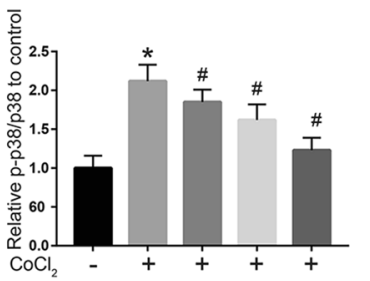
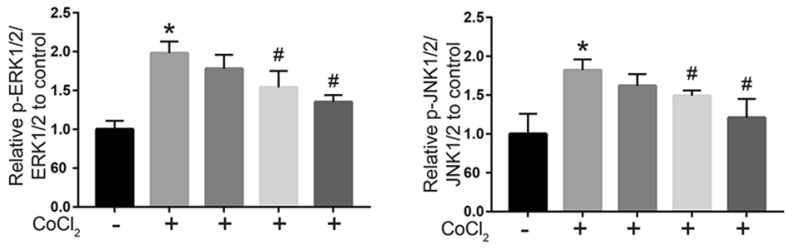
Nesfatin-1
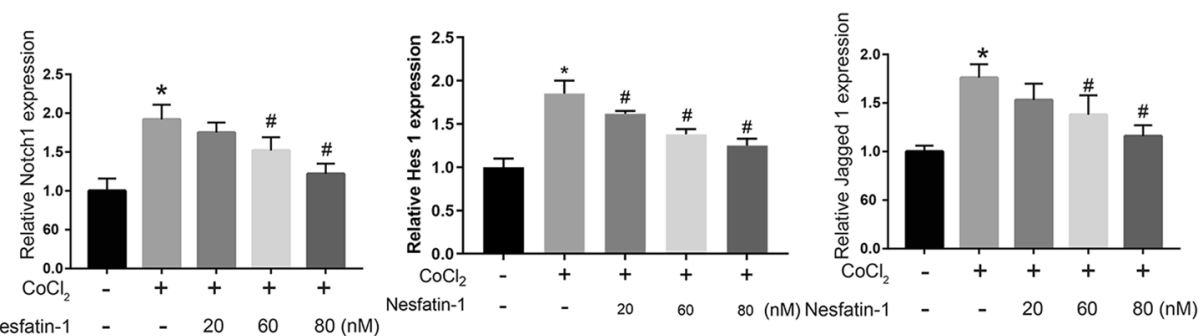

Fig. 5 Nesfatin-1 protected $\mathrm{H} 9 \mathrm{c} 2$ cells against $\mathrm{COCl}_{2}$-induced hypoxic injury by inhibiting MAPK and Notch1 signaling pathways. $\mathrm{H} 9 \mathrm{c} 2$ cells were treated with $800 \mu \mathrm{M} \mathrm{CoCl}_{2}$ for $48 \mathrm{~h}$ before treatment with nesfatin-1 (20,60 and $\left.80 \mathrm{nM}\right)$ for $24 \mathrm{~h}$. The expression of MAPK pathway members (A) and Notch 1 pathway members (B) was detected by Western blot. Data are presented as mean $\pm \mathrm{SD}$. ${ }^{*} p<0.05 \mathrm{vs}$. control group $(0 \mu \mathrm{M}$ CoCl $)$; \#p $<0.05$ vs. $\mathrm{CoCl}_{2}$ alone group $\left(800 \mu \mathrm{M} \mathrm{CoCl}_{2}\right.$ and $0 \mathrm{nM}$ nesfatin- 1$)$

reported that Notch1 expression was downregulated in hypoxia-induced $\mathrm{H} 9 \mathrm{c} 2$ myocardial cells, and relaxin protected cardiomyocytes against hypoxia/reoxygenation injury by enhancing Notch-1 signaling. Hu et al. [46] and $\mathrm{Yu}$ et al. [47] have reported that activated Notch1 signaling attenuated hypoxia-induced injury in cardiomyocytes by reducing programmed cell death. These reports suggest that activated Notch-1 signaling might play a protective role in hypoxia-injured cardiomyocytes. However, Zhu et al. [48] has found that curcumin alleviates hypoxia/reoxygenation-induced cardiomyocyte injury by inhibiting Notch signaling, consistent with our findings in the present study. This discrepancy might be due to different mechanisms to induce hypoxia and needs to be further explored.

Our study has some limitations. First, our results were obtained by using rat embryonic cardiomyocyte H9c2 cell line and need to be confirmed in other cardiomyocyte cell lines. Second, nesfatin-1 concentration to exert its potential therapeutic or toxic effects may vary in different cells. Therefore, our findings need to be further confirmed in co-cultured cell models.

\section{Conclusions}

In summary, we demonstrated that nesfatin-1 effectively protects cardiomyocytes from $\mathrm{CoCl}_{2}$-induced hypoxic injuries by inhibiting MAPK and Notch1 signaling pathways, suggesting that nesfatin-1 might be a potential therapeutic agent against hypoxic injuries to cardiomyocytes.

\section{Acknowledgements}

Not Applicable.

\section{Authors' contributions}

Mingchen Li: study concepts, literature research, clinical studies, data analysis, experimental studies, manuscript writing and review; Yuan Ren: study design, literature research, experimental studies and manuscript editing; Kai Li: definition of intellectual content, data acquisition and statistical analysis. All authors read and approved the final manuscript.

\section{Funding}

Not Applicable.

\section{Availability of data and materials}

The datasets produced and analyzed during the current study are available from the corresponding author on reasonable request.

\section{Declarations}

Consent for publication

Not applicable.

\section{Competing interests}

All authors have no competing interests and declare that we do not have any commercial or associative interest that represents a competing interest in connection with the work submitted.

\section{Author details}

${ }^{1}$ Department of Cardiology, The People's Hospital of Jiulongpo, No. 31 Baixin Road, Baishiyi, Jiulongpo, 401329 Chongqing, People's Republic of China. ${ }^{2}$ Heart Center, The First Affiliated Hospital of Xinjiang Medical University, Xinjiang 830054 Urumqi, People's Republic of China.

Received: 14 November 2020 Accepted: 30 June 2021

Published online: 13 September 2021 


\section{References}

1. Ratcliffe P, Koivunen P, Myllyharju J, Ragoussis J, Bovée JV, Batinic-Haberle I, et al. Update on hypoxia-inducible factors and hydroxylases in oxygen regulatory pathways: from physiology to therapeutics. Hypoxia (Auckland NZ). 2017:5:11-20.

2. Romero Jl, Holubiec MI, Tornatore TL, Rivière S, Hanschmann EM, KöllikerFrers RA, et al. Neuronal Damage Induced by Perinatal Asphyxia Is Attenuated by Postinjury Glutaredoxin-2 Administration. Oxid Med Cell Longev. 2017:2017:4162465

3. Chouchani ET, Pell VR, Gaude E, Aksentijević D, Sundier SY, Robb EL, et al. Ischaemic accumulation of succinate controls reperfusion injury through mitochondrial ROS. Nature. 2014;515:431-5.

4. O'Driscoll BR, Howard LS, Davison AG. Oxygen in myocardial infarction. Maintain normoxaemia until more evidence is available. BMJ. 2010;341:c3715.

5. Ranjbar Taklimie F, Gasterich N, Scheld M, Weiskirchen R. Hypoxia Induces Astrocyte-Derived Lipocalin-2 in Ischemic Stroke. Int J Mol Sci. 2019;20:1271

6. Kuo CY, Chiu YC, Lee AY, Hwang TL. Mitochondrial Lon protease controls ROS-dependent apoptosis in cardiomyocyte under hypoxia. Mitochondrion. 2015;23:7-16.

7. Wang S, Cheng ZY, Chen XJ, Xue HZ. Ulinastatin protects rats with myocardial infarction by activating Nrf2/NOS pathway. Eur Rev Med Pharmacol Sci. 2018;22:8990-8.

8. Sun Y, Liu WZ, Liu T, Feng X, Yang N, Zhou HF. Signaling pathway of MAPK ERK in cell proliferation, differentiation, migration, senescence and apoptosis. J Recept Signal Transduct Res. 2015:35:600-4.

9. Wen Y, Liu R, Lin N, Luo H, Tang J, Huang Q, et al. NADPH Oxidase Hyperactivity Contributes to Cardiac Dysfunction and Apoptosis in Rats with Severe Experimental Pancreatitis through ROS-Mediated MAPK Signaling Pathway. Oxid Med Cell Longev. 2019;2019:4578175.

10. Cong Z, Ye G, Bian Z, Yu M, Zhong M. Jagged-1 attenuates LPS-induced apoptosis and ROS in rat intestinal epithelial cells. Int J Clin Exp Pathol. 2018;11:3994-4003

11. Jin M, Wang J, Ji X, Cao H, Zhu J, Chen Y, et al. MCUR1 facilitates epithelialmesenchymal transition and metastasis via the mitochondrial calcium dependent ROS/Nrf2/Notch pathway in hepatocellular carcinoma. J Exp Clin Cancer Res. 2019:38:136.

12. Oh -IS, Shimizu H, Satoh T, Okada S, Adachi S, Inoue K, et al. Identification of nesfatin-1 as a satiety molecule in the hypothalamus. Nature. 2006;443:709-12.

13. Öztürk Özkan G. Effects of Nesfatin-1 on Food Intake and Hyperglycemia. J Am Coll Nutr. 2020;39:345-51.

14. Mori Y, Shimizu H, Kushima H, Saito T, Hiromura M, Terasaki M, et al. Nesfatin-1 suppresses peripheral arterial remodeling without elevating blood pressure in mice. Endocr Connect. 2019;8:536-46.

15. Wang $X Q$, Zheng $Y$, Fang PF, Song XB. Nesfatin-1 is a potential diagnostic biomarker for gastric cancer. Oncol Lett. 2020;19:1577-83.

16. Liu GM, Xu ZQ, Ma HS. Nesfatin-1/Nucleobindin-2 Is a Potent Prognostic Marker and Enhances Cell Proliferation, Migration, and Invasion in Bladder Cancer. Dis Markers. 2018:4272064

17. Kan JY, Yen MC, Wang JY, Wu DC, Chiu YJ, Ho YW, et al. Nesfatin-1/Nucleobindin-2 enhances cell migration, invasion, and epithelial-mesenchymal transition via LKB1/AMPK/TORC1/ZEB1 pathways in colon cancer. Oncotarget. 2016;7:31336-49.

18. XuY, Pang $X$, Dong M, Wen F, Zhang Y. Nesfatin-1 inhibits ovarian epithelial carcinoma cell proliferation in vitro. Biochem Biophys Res Commun. 2013;440:467-72

19. Nazarnezhad S, Rahmati M, Shayannia A, Abbasi Z, Salehi M, Khaksari M. Nesfatin-1 protects PC12 cells against high glucose-induced cytotoxicity via inhibiting oxidative stress, autophagy and apoptosis. Neurotoxicology. 2019;74:196-202.

20. Chang J, Yang B, Zhou Y, Yin C, Liu T, Qian H, et al. Acute Methylmercury Exposure and the Hypoxia-Inducible Factor-1a Signaling Pathway under Normoxic Conditions in the Rat Brain and Astrocytes in Vitro. Environ Health Perspect. 2019;127:127006

21. Niu N, Li Z, Zhu M, Sun H, Yang J, Xu S, et al. Effects of nuclear respiratory factor-1 on apoptosis and mitochondrial dysfunction induced by cobalt chloride in H9C2 cells. Mol Med Rep. 2019;19:2153-63.

22. He F, Wu Q, Xu B, Wang X, Wu J, Huang L, et al. Suppression of Stim 1 reduced intracellular calcium concentration and attenuated hypoxia/reoxygenation induced apoptosis in H9C2 cells. Biosci Rep. 2017;37:BSR20171249.

23. Tello D, Balsa E, Acosta-Iborra B, Fuertes-Yebra E, Elorza A, Ordóñez Á, et al Induction of the mitochondrial NDUFA4L2 protein by HIF-1a decreases oxygen consumption by inhibiting Complex I activity. Cell Metab. 2011;14:768-79.

24. Rhodes CE, Varacallo M, Physiology. Oxygen Transport. StatPearls. Treasure Island (FL): StatPearls Publishing Copyright (c 2020. StatPearls Publishing LLC.; 2020.

25. Wang G, Cui J, Guo Y, Wang Y, Kang L, Liu L. Cyclosporin A Protects H9c2 Cells Against Chemical Hypoxia-Induced Injury via Inhibition of MAPK Signaling Pathway. Int Heart J. 2016;57:483-489.

26. Chen R, Xu J, She Y, Jiang T, Zhou S, Shi H, et al. Necrostatin-1 protects C2C12 myotubes from CoCl2-induced hypoxia. Int J Mol Med. 2018;41:2565-72.

27. Piret JP, Mottet D, Raes M, Michiels C. CoCl2, a chemical inducer of hypoxia-inducible factor-1, and hypoxia reduce apoptotic cell death in hepatoma cell line HepG2. Ann N Y Acad Sci. 2002;973:443-7.

28. Pang Z, Wang T, Li Y, Wang L, Yang J, Dong H. Liraglutide ameliorates COCl2-induced oxidative stress and apoptosis in $\mathrm{H} 9 \mathrm{C} 2$ cells via regulating cell autophagy. Exp Ther Med. 2020;19:3716-3722.

29. Sun Y, Jiang $C$, Hong $H$, Liu J, Qiu L, Huang Y, et al. Effects of hypoxia on cardiomyocyte proliferation and association with stage of development. Biomed Pharmacother. 2019;118:109391.

30. Qin L, Fan S, Jia R, Liu Y. Ginsenoside Rg1 protects cardiomyocytes from hypoxia-induced injury through the PI3K/AKT/mTOR pathway. Pharmazie. 2018:73:349-55.

31. Du J, Liu J, Zhen J, Yang ST, Zheng EL, Leng JY. Astragaloside IV protects cardiomyocytes from hypoxia-induced injury by down-regulation of IncRNA GAS5. Biomed Pharmacother. 2019;116:109028.

32. Shi YN, Zhang $X Q$, Hu ZY, Zhang CJ, Liao DF, Huang HL, et al. Genistein Protects H9c2 Cardiomyocytes against Chemical Hypoxia-Induced Injury via Inhibition of Apoptosis. Pharmacology. 2019;103:282-90.

33. Zhang X, Xiao C, Liu H. Ganoderic Acid A, Protects Rat. H9c2 Cardiomyocytes from Hypoxia-Induced Injury via Up-Regulating miR-182-5p. Cell Physiol Biochem. 2018;50:2086-96.

34. Han Q, Li G, Ip MS, Zhang Y, Zhen Z, Mak JC, et al. Haemin attenuates intermittent hypoxia-induced cardiac injury via inhibiting mitochondrial fission. J Cell Mol Med. 2018;22:2717-26.

35. Waza AA, Hamid Z, Bhat SA, Shah NUD, Bhat M, Ganai B. Relaxin protects cardiomyocytes against hypoxia-induced damage in in-vitro conditions: Involvement of Nrf2/HO-1 signaling pathway. Life Sci. 2018;213:25-31.

36. Gu Y, Gao L, Chen Y, Xu Z, Yu K, Zhang D, et al. Sanggenon C protects against cardiomyocyte hypoxia injury by increasing autophagy. Mol Med Rep. 2017;16:8130-6.

37. Wei J, Xu H, Shi L, Tong J, Zhang J. Trimetazidine protects cardiomyocytes against hypoxia-induced injury through ameliorates calcium homeostasis. Chem Biol Interact. 2015;236:47-56.

38. Gruzewska K, Michno A, PawelczykT, Bielarczyk H. Essentiality and toxicity of vanadium supplements in health and pathology. J Physiol Pharmacol. 2014;65:603-11.

39. van Empel VP, Bertrand AT, Hofstra L, Crijns HJ, Doevendans PA, De Windt LJ. Myocyte apoptosis in heart failure. Cardiovasc Res. 2005:67:21-9.

40. Sinha K, Das J, Pal PB, Sil PC. Oxidative stress: the mitochondria-dependent and mitochondria-independent pathways of apoptosis. Arch Toxicol. 2013;87:1157-80

41. Smith KA, Waypa GB, Schumacker PT. Redox signaling during hypoxia in mammalian cells. Redox Biol. 2017;13:228-34.

42. Liu Z, Ding Y, Ye N, Wild C, Chen H, Zhou J. Direct Activation of Bax Protein for Cancer Therapy. Med Res Rev. 2016;36:313-41.

43. Shen Y, White E. p53-dependent apoptosis pathways. Adv Cancer Res. 2001:82:55-84

44. Cheng $\mathrm{Cl}$, Lee YH, Chen PH, Lin YC, Chou MH, Kao YH. Cobalt chloride induces RhoA/ROCK activation and remodeling effect in $\mathrm{H} 9 \mathrm{C} 2$ cardiomyoblasts: Involvement of PI3K/Akt and MAPK pathways. Cell Signal. 2017:36:25-33.

45. Boccalini G, Sassoli C, Formigli L, Bani D, Nistri S. Relaxin protects cardiac muscle cells from hypoxia/reoxygenation injury: involvement of the Notch-1 pathway. FASEB J. 2015;29:239-49. 
46. Hu Y, Zheng Z, Pan H, Peng J, Luo Y, Cui B, et al. Notch1 signaling activation protected myocardium against hypoxia injury via reducing programmed cell death. Pak J Pharm Sci. 2017;30:2429-33.

47. Yu B, Song B. Notch1 signalling inhibits cardiomyocyte apoptosis in ischaemic postconditioning. Heart Lung Circ. 2014;23:152-8.

48. Zhu $\mathrm{P}$, Yang $\mathrm{M}, \mathrm{He} \mathrm{H}$, Kuang Z, Liang $\mathrm{M}$, Lin $\mathrm{A}$, et al. Curcumin attenuates hypoxia/reoxygenation-induced cardiomyocyte injury by downregulating Notch signaling. Mol Med Rep. 2019;20:1541-50.

\section{Publisher's Note}

Springer Nature remains neutral with regard to jurisdictional claims in published maps and institutional affiliations.
Ready to submit your research? Choose BMC and benefit from:

- fast, convenient online submission

- thorough peer review by experienced researchers in your field

- rapid publication on acceptance

- support for research data, including large and complex data types

- gold Open Access which fosters wider collaboration and increased citations

- maximum visibility for your research: over $100 \mathrm{M}$ website views per year

At BMC, research is always in progress.

Learn more biomedcentral.com/submissions 